Journal of Teacher Education for Sustainability

vol. 11, no. 1, pp. 65-74, 2009

\title{
NON-FORMAL ENERGY EDUCATION IN THE CONTEXT OF SUSTAINABILITY: PERSPECTIVE OF LATVIAN EDUCATORS
}

\author{
Lolita Jonāne and Antonijs Salìtis \\ Daugavpils University, Latvia
}

\begin{abstract}
Energy as one of the main concepts of sustainable development currently challenges the society in general and education in particular. The paper reflects on study that is a part of EU COMENIUS project. It explores the situation in Latvia with energy topic in non-formal education in the context of education for sustainable development. The teachers and out-of-school experts' views on non-formal energy education are identified using the constructed tools in relation to: 1) teaching materials; 2) readiness to teach energy education, and 3) out-of-school places for this topic. Structured interview and survey were conducted with 20 experts of out-of-school places and 50 teachers. Both qualitative and quantitative data analysis methods were applied. Different conceptual approaches, the best practice examples, challenges and needs, and the main chances for improvement and development in the field were inferred from the data. The recommendations could be useful both locally and globally for education policymakers, teacher training institutions, administrators for improving connections between formal and non-formal education, pre-service, and in-service teacher training.
\end{abstract}

Key words: energy; energy education; teachers; non-formal education; sustainable development.

Changes, interaction, globalisation, and sustainable development are the key words that characterize processes in contemporary society. Energy is central to sustainable development (SD) and poverty reduction efforts. It affects all aspects of development social, economic, and environmental - including livelihoods, access to water, agricultural productivity, health, and population levels (UN, 1992a). Globalisation offers many new opportunities but creates also new and often unexpected challenges and problems. The most urgent problem considered from a global perspective is global warming. The global scientific community "is more than $95 \%$ certain that climate change is occurring, and that most of the temperature increases over the past fifty years result from human greenhouse emissions, specially carbon dioxide from burning fossil fuels" (Brunsell, Jones, Jackson, \& Feddema, 2008, p. 4). Another cause for this problem is fast economical 
development and rapid growth of energy use in households. This complex challenge of energy and sustainable development was highlighted at the United Nations Conference on Environment and Development, held in Rio de Janeiro (UN, 1992b).

In the context of climate protection, humanity must diminish usage of energy per each inhabitant or utilize energy resources and materials maximally friendly for environment. The World Summit on Sustainable Development (Heinrich Boell Foundation, 2002) urged people to accelerate the development, dissemination and deployment of affordable and cleaner energy efficiency and energy conservation technologies. Energy effectiveness in domestic usage and economy is not only challenging but also necessary for all society and education (UNESCO, 2004). The subject of environmentally friendly energy covers social as well as scientific competences and focuses on the threat of the climate change. The main aspect for global and local problem solving regarding energy use and climate protection is education of individuals and entire society. It can be implemented as both formal and non-formal education at school and out-of-school education places (OSEP). The new challenge in this area is to integrate the high effectiveness of learning at OSEP into school education. In this article, the efficient usage of energy and renewable energies will serve as the subject to analyse the potentials, needs of teacher education and to create advanced training courses for teachers.

On the global scale, various organizations, e.g., NIOST (2007), NREL (2008), CREATE (2008), etc., are working in the field of non-formal education and energy education. Some of them have conducted a series of projects (NEED, 2007; $\mathrm{RnE}^{2} \mathrm{EW}$, n.d., etc.), researches, developed standards, programs, and training. Education staff conducts educational outreach events, hands-on activities, and professional development seminars at schools, conventions, competitions, trade shows, fairs and other exhibitions for students, teachers, and consumers.

\section{Energy education in formal and non-formal context: situation in Latvia}

Non-formal education has just recently started to develop in Latvia (Kravale, 2006). Ministries and councils are currently elaborating and specifying the conception of nonformal education, its structure and forms of procedure. In Latvia, non-formal education is implemented by diverse institutions and individuals, and higher education institutions. Non-formal education here is often referred to the education of interests, thus reducing the possibilities of the development of non-formal education. The areas of interest education are dancing, music, sports, technical design, theatre, art, and environmental education. Only few examples are known to be related to energy and climate protection activities in non-formal education of Latvia. Therefore this research focuses on the energy topic in school curricula in general and possibilities of integration of formal and non-formal education while teaching this topic.

Analysis of the national regulations for formal education in the field of energy education shows that the situation here is much better. In the National Standards for Basics of Technology and Science (including Mathematics, Nature Studies, Physics, Chemistry, Biology, Geography, IT), main tasks for primary school are to provide opportunities to acquire the basic knowledge about rules of mathematics and natural sciences, usage of IT, to foster understanding of the wholeness of nature. This field is oriented to develop the basic research skills by observing nature, using mathematical 
models and IT. The tasks that are especially important for this field are to develop understanding about the connection between achievements in mathematics and science, technology, human daily life, economic activities and environment, to create a need to care for the environmental conservation and health, as well as to develop the diverse learning experience (CM, 2006, p.6). Evaluated from the perspective of the energy topic, Standards of Nature Studies for grades 1-6 contain the following items:

- Students recognize the energy sources, can discern renewable and nonrenewable sources of energy and display a positive attitude and practical behaviour toward the efficient consumption of energy and natural resources, they display awareness about the changes in nature created by human economic activities;

- Students know the most important advancements in Science and discoveries in the field of environment protection, they understand the implications of Science and technology for the improvement of human conditions and the impact of their inappropriate use on human health and environment, they participate in activities related to the improvement of environmental quality and solution of local problems.

Also, some subjects in the field of Basics of Technology and Science (Physics, Chemistry, Geography, Household and Technologies) (grades 8-9) include some themes and learning objectives that are closely related to energy topic.

In 2005-2008, Ministry of Education and Science of Latvia accomplished the EU/ ESF Latvian National Program Development and Improvement of Subject Curricula in Natural Science, Technology, and Mathematics in Secondary Education Project Curriculum Development and In-Service Teacher Training in Science, Mathematics, and Technology. The project aimed to update the curriculum and to improve the quality of teaching and learning in Science (Physics, Chemistry, Biology, and Nature Studies) and Mathematics for secondary school. Current Regulations on the National Standards in Secondary Education and Standards in Secondary Education School Subjects (CM, 2008) also set task to improve students' understanding about sustainable development and its relationships with environmental, economic, and social processes.

Latvian NGOs working in environmental, energy and social field have set up several local projects on energy efficiency. These NGOs are very motivated to spread the message. The motivation and positive attitude of Latvian NGOs towards energy efficiency is illustrated by their large response to a tender for energy efficiency projects. Six projects were awarded funding and are being implemented. The NGOs play an important role in the awareness raising activities and this stimulates the recognition of these organisations in Latvian society.

Some practical examples of non-formal energy education:

- International Project Energy is our Future is intended to enhance and to support energy education across the curriculum in schools. It helps teachers raise their students' awareness on how to save energy, what energy consumption means, and the importance of renewable energy. The project also aims to inspire students to influence behaviours in their nearest environment, such as families and local communities. This project is designed for teachers of sciences, languages, arts, social sciences and ICT in lower and upper secondary school classes. 
- LATVENERGO is a state-owned energy utility whose core business is generation and sale of electricity and thermal energy. It is one of environmentally friendly energy companies in Europe. It ensures introduction of modern technologies in economy, social life, and organizes competitions for students. LATVENERGO has created a range of educational materials - computer games, electric safety issues book "Know Electricity", some movie series "Long Live Children”, posters, etc.

The Latvian national TV program Vides fakti [Environmental facts] presents a topic on energy efficiency, e.g. house ventilation and windows, structure of energy tariffs, project financing issues, EU energy efficiency, etc. In total, 16 items have been broadcasted and reached a large audience. The form and presentation of the video clips are specifically adapted to people aged $25-35$. The clips will be used to make a film on energy efficiency for the distribution in all schools in Latvia.

\section{Investigation of non-formal energy education in Latvia}

The empiric study presented in this paper was conducted as a part of EU COMENIUS Lifelong Learning Program, multilateral project Inspire School Education by Non-Formal Learning, in the spring of 2008. Latvia, Germany, and Poland participate in this project as international partners. The main objective of the project is to create synergies and links between OSEP and curricular learning, thus improving the base of knowledge of European pupils. First outcome of the project would be an overview about existing concepts of combining learning at out-of-school places with formal learning at school in the participating countries, focused on the subject of environmentally friendly use of energy. This project therefore aims to provide additional offers for teachers at OSEP, which can be integrated into didactic concepts of school education. Thus, new places for in-service training of teachers in addition to traditional ones will emerge. They will be more intensively adapted to the needs and demands of school education in the context of SD. In order to improve the quality, attractiveness and accessibility of lifelong learning and in-service teacher training, an investigation of existing situation is necessary. The presented study focuses solely on the Latvian situation and is aimed toward the identification of Latvian teachers and other educators' views regarding the non-formal energy education in the context of sustainability. The study will explore teachers and experts' perception about the possibilities of teaching/learning about energy at OSEP in Latvia. The main aspects of the study will be related to teaching materials, teacher training, their readiness for energy education, and possibilities of OSEP for energy education.

\section{Sample}

For the purpose of research, two different samples were collected: a sample of out-ofschool education experts was chosen for interview, while a sample of teachers was selected for the survey.

The interview sample of experts $(\mathrm{N}=20)$ consisted of 5 males and 15 females and represented teacher training institutions $(n=5)$, out-of-school education places $(n=7)$ and different schools $(n=8)$ from all regions of Latvia. The specialities of experts were 
natural sciences $(n=15)$, social sciences $(n=3)$, engineering $(n=1)$, and agronomy $(n=1)$. The work experience of teacher educators in the average was over 31 year. The teachers' pedagogical experience was in the average 28 years. Three teachers were doctoral students. The pedagogical experience of OSEP experts was in the average 11 years. The majority of the experts had some experience of administrative work.

The teachers $(\mathrm{N}=50)$ involved in the survey ( $6 \%$ male, $94 \%$ female) represented different types of schools: primary schools $(12 \%)$, basic schools $(20 \%)$, secondary schools $(58 \%)$, and other schools $(10 \%)$ from all regions of Latvia. Their pedagogical experience was 1-40 years (in average 18 years). Approximately half of the sample were teachers of natural science; the other half were specialised in other disciplines.

Therefore, structure and qualitative features of the samples for survey and interview confirm their validity for the presented research.

\section{Methods, procedure and data analysis}

\section{Interview}

The aim of interview was to: 1 ) reveal the real situation concerning the integration of OSEP and school curricula in relation to energy education; 2) to discover the impact of out-of-school places on students' learning, especially on social competences, knowledge in Science, and knowledge on environment. Structured interview with 14 questions was created by INSPIRE project team from Latvia. In this research the answers for seven interview questions targeting solely the energy education were analysed. The interview contained questions like "What kind of teaching materials (regarding content, structure, etc.) dealing with the topic of energy in out-of-school places you would be happy to use as a teacher?" and "What eventual challenges and concerns do you see regarding the integration of school and out-of-school places specifically for the acquisition of energy related topics?"

While arranging the interview, the time, place, and length of interview were coordinated (up to 60 minutes). Permission was asked for audio recording of the interview. The level of confidentiality of interview data was decided (the results of interview mainly appear in summarised form; in need of quoting, the respondents are depicted in the project reports only in coded form, etc.). The respondents were briefly familiarized with the project and its research topic and informed about the aim of the interview. Before the interviews, the demographic data were collected from the participants. All the interviews were audio-taped and transcribed to create a written protocol.

Since the interview questions were focused on few specific topics, the interview data analysis was simple enough to allow the creation of sub-themes, as guided by research aim and topics. Similar individual themes were clustered and appropriate language to describe them was selected. The interview data later was triangulated with the data from teachers' survey.

\section{Survey}

The survey conducted within the study was applied to obtain both quantitative and qualitative information from the teachers that could be used as the data complementing and adding some specificity to the main data obtained from the interviews with experts. 
A structured 18-item survey with open-ended and closed questions was created by the INSPIRE project team from Latvia. In this study, the researchers analyzed only the last four questions of the survey related to energy topic in non-formal education. The example of survey questions: "Name extracurricular places in your town (district) where your pupils could master the topics about energy?"

Respondents gave their consent for confidentiality and anonymity of their answers before the survey. The answers on the survey questions were collected both in hardpaper and electronic form. The respondents were briefly introduced to the research topic and informed about the aim of the survey. The survey started with information about the demographic data of respondents. Both qualitative and quantitative data analysis methods were applied.

\section{Results}

The experts' answers on interview questions and the teachers' answers on survey questions were analyzed in consideration of three aspects: 1) curriculum and teaching materials on energy education; 2) teacher training for energy education; and 3) OSEP and its staff for energy education. Though, the answers for several questions differed for two sample groups, the more detailed analysis of these differences and their reasons would become the aim of further studies. Because of the limited space, the results of two research instruments are presented mainly in a form of aggregated summary, using just a few quantitative indices to illustrate the most impressive findings or if it was impossible to avoid the usage of numbers.

\section{Curriculum and teaching materials on energy education}

The experts admitted that in Latvia energy topic is formally included in the present day educational curriculum for all stages of education. However, the implementation of this topic creates a challenge because of axiological issues, improper approach to the subject, limitation to only some disciplines. New secondary school programs for Nature Studies, Physics, Biology, and Chemistry provide a closer attention to improvement of students' understanding about sustainable development and the relationships of its environmental, economic and social aspects, also concerning the energy use.

Answering the question about the teaching materials (regarding content, structure, etc.) on the topic of energy in OSEP, the majority of experts recognized that there are enough materials for environmental education in both printed and in electronic form. However, they indicated to the lack of proper materials for energy topic. Only two items were mentioned regarding the energy topic - materials of LATVENERGO and brochure with DVD on the types of alternative energy in Latvia (see: http://www. latvenergo.lv/portal/page? pageid $=73,56674 \& \mathrm{dad}=$ portal $\&$ schema=PORTAL). Surprisingly, the teachers mentioned longer list of materials. One teacher wrote that topics of energy are included in Nature Studies, Physics, Chemistry, and Geography textbooks for formal education.

It is generally accepted that these materials can be used for both formal and nonformal education. While teacher trainers admitted that there are lot of teaching materials and criticised their quality, teachers and OSEP staff expressed the wish to have more materials. They also named different materials such as: 
- Journal Vides Vèstis [Environmental messenger] published by the Friends of the Earth Latvia (see: http://www.videsvestis.lv/default.asp?english);

- journal TERRA published by the University of Latvia (see: http://www.lu.lv/ terra/);

- professional journal Energétika un automatizācija [Power industry and automation] (see: http://www.baltenergy.com/);

- Internet resources: http://www.futurenergia.org/ww/en/pub/futurenergia/ about/about.htm; http://www.zalajosta.lv/; http://www.zalais.lv/en/; http:// www.windenergy.lv/en/projekti.html; http://www.liis.lv/vi/vienerg.htm; etc.

Teachers wanted more updated technological approach to such materials and expressed rather detailed view on the content and pedagogy of such materials.

\section{Teacher training for energy education}

The analysis of answers on the question about the readiness of teachers to organize the cognition of real life topics and development of skills for reasonable behaviour for their students (for instance, the cognition of different topics on energy) show that they are not quite unanimous. While teachers were more optimistic, teacher educators and OSEP experts did not see the situation as positively as teachers did. Teachers suggested many ideas how to improve this situation: in order to organize learning of energy topic, teachers themselves need to have a strong scientific background, OSEP staff needs proper equipment and time, teachers have to prepare themselves for this topic by visiting OSEP connected with energy education. Those experts who said that teachers were not ready for energy education suggested:

- To raise the individual importance of such topics for teachers, increase the number of students enrolled in Science teacher programs;

- To organize teacher pre-service and in-service training (also in a non-formal way);

- To publish brochures, organize the visits to firms, OSEP;

- To systematize and to plan materials for the whole school year, creating the plan of topics for school subject, tasks that could be used as the training for behavioural models in different situations of life;

- To organize extra courses for students on energy topic with final tests and certificates.

\section{Out-of-school learning places for energy education}

When asked to mention OSEP that offer an opportunity for students to get an experience in understanding of real life urgencies, teachers were able to mention the large number of out-of-school places. The universities would probably be able to provide more scientific information about the topic. Except just a few of them, none are educational centres established specially for energy topic. Some administrative problems could be forecasted concerning visits to several of mentioned places since they usually do not consider education as one of their functions. The most frequently mentioned places were: LATVENERGO, hydroelectric power stations (HEPS) on small rivers, thermoelectric power stations, Faculties of Science. 
Speaking about the eventual challenges and concerns in relation to the integration of school and OSEP specifically for the acquisition of energy related topics, the respondents admitted that Latvia does not have special OSEP places or organizations, which would support students for learning of energy topic. Other places connected with energy have many problems and they should understand the situation at school better. Experts concluded than some solutions were suggested for the improvement of situation: to motivate and to train teachers, to develop cooperation (e.g., cooperation between schools and HEPS or other enterprises to help students in their research work), to find time for teaching/learning out-of-school, to develop teaching materials, and to organize in-service training courses.

Out of 121 topics mentioned as carried out in out-of-school places by 50 teachers, only 5 topics were connected with energy. However, the positive fact is that of 17 topics that created the most noticeable changes in pupils, 13 topics were connected with nature and environmental protection. Theme "Environmental research and monitoring" received the second rank among 11 topics. This result is a rather good sign considering that the teachers surveyed teach social sciences and humanities twice as often as Science subjects.

The participants were not too willing to offer some new activities for the students as to reach a more comprehensive understanding of energy topic and development of skills for reasonable behaviour, beyond those that were already mentioned. Teacher training institutions showed larger interest in energy topic since they have all the necessary equipment and materials, such as solar cells or batteries, equipment for creating simple wind generator or dynamo machine. HEPS staff is also willing to cooperate and use its potential for students learning and research.

The lists of places teachers have already visited and places they would suggest to visit do not differ much. The only educational organizations in this list were Daugavpils University and Riga Children Nature Studies School. It can be concluded that in Latvia there is a scarcity of OSEP where students could master the topic of energy.

\section{Conclusions}

Some countries do not have yet stable traditions in integration of formal and nonformal learning. Latvia is still searching for its functions, roles, approaches, and methods. On the global scale, non-formal education and energy education are considered as important components of education for sustainable development. The significance of these trends is connected with the current state of the world in terms of economic, ecologic, social and even political issues. Non-formal education as one of the aspects of education has recently been reflected in many forms: articles, books, Internet resources, etc. However, the energy education as a more specific feature has received coverage on a smaller scale. Though, more practical implication of such education (projects, training opportunities, etc.) is noticeable in a world, the research articles and monographs are still needed here. The energy topic (among the other topics on environmental education and education for sustainable development) is included in educational guidelines, though only a few out-of-school education places carry out energy education in Latvia. Very few teaching units about energy topic are designed yet. 
It is evident that ever changing education in Latvia still needs the legislation, curricula and standards that would serve more visionary, anticipatory and future-oriented functions than they carry out today. Energy topic is included in educational guidelines side by side with other important topics connected with environmental education and education for sustainable development. Since the educational legislation in Latvia does not mention education for sustainable development as the central item explicitly, this is still the further aim of advocates, politicians, researchers and practitioners. Actually, only a few OSEP in Latvia could be mentioned that carry out educational functions regarding energy topic. These places mostly do not have yet the elaborated teaching units about energy topic. Also activities on energy topic are not used on regular basis and as the research shows, such a topic is not among the most popular for teachers.

The main chances for improvement and development in this field focus more on teacher training for: 1) the integration of formal/non-formal learning; 2) cooperation with out-of-school places; 3) the updated secondary curriculum in Science and Mathematics that would connect the learning with the life issues and accustom teachers and students to more research and experience-oriented learning.

Since the non-formal learning in OSEP is underdeveloped as a national system in Latvia, the major challenges should be approached systematically:

- At the state level: development of legislation and systemic approach to the issue as well as more research are needed. Revision of curriculum, elimination of over-centralization, sustainable financing, and creation of more out-ofschool places are the main questions.

- At the level of teachers: relevant pre-service/in-service training is the main problem, teachers need to revive their motivation and to find extra time. Besides, focused teaching materials and aids and cooperation with out-ofschool places are prerequisites for the further development.

- At the level of students: motivation, responsibility, self-discipline, and time are the keywords.

- At the extracurricular education level: equipment, training for educational personal, teaching materials, motivation, coordination of offer with students' needs, interests, and curriculum, leadership, self-advertisement, cooperation with schools, and time can be perceived as the challenge.

- At the community level: interest and motivation of parents as well as the family traditions need to be developed as to include the visits to out-of-school places related to natural sciences and environmental education.

As can be seen from the description, the common challenges and needs are associated mainly with the financial means, problems at the teachers' level involve a need for cooperation between/inside the school and OSEP.

The project is still under its way and hopefully at least some challenges can turn into promising undertakings regarding the non-formal energy education in Latvia. Energy is our future and we all need some inspiration to ensure its sustainability and security. 


\section{References:}

Brunsell, N. A., Jones, A. R., Jackson, T. L., \& Feddema, J. J. (2008). Seasonal trends in air temperature and precipitation in IPCC AR4 GCM output for Kansas, USA: Evaluation and implications. In review: International Journal of Climatology, USA. Cabinet of Ministers (CM). (2006). Regulations on the National Standards in Primary Education and Standards in Primary Education School Subjects. Latvijas Vēstnesis [Messenger of Latvia], 204 2006.12.22.

Cabinet of Ministers (CM). (2008). Regulations on the National Standards in Secondary Education and Standards in Secondary Education School Subjects. Latvijas Vēstnesis [Messenger of Latvia], 18.09.2008 No.145 (6147).

Centre for Research, Education and Training in Energy (CREATE). (2008). Retrieved January 14, 2009, from http://www.create.org.uk/

Heinrich Boell Foundation. (2002). World Summit on Sustainable Development. Retrieved March 31, 2009, from http://www.wprldsummit2002.org/

Kravale, M. (2006). Youth non-formal education in Latvia. Unpublished doctoral dissertation, Daugavpils University, Daugavpils, Latvia.

National Energy Education Development Project (NEED). (2007). Retrieved January 10, 2009, from http://www.need.org/info.php

National Institute of Out-of-school Time (NIOST). (2007). Retrieved January 15, 2009, from http://www.niost.org/about/index.html

National Renewable Energy Laboratory (NREL) (2008). Learning about renewable energy. Retrieved February 1, 2009, from http://www.nrel.gov/learning/

Renewable energy and efficiency education on wheels ( $\left.\mathrm{RnE}^{2} \mathrm{EW}\right)$. (n.d.). Retrieved January 24, 2009, from www.rne2ew.org

UNESCO. (2004). Education for Sustainable Development. United Nations Decade (2005-2014). Retrieved January 13, 2009, from http://portal.unesco.org/education/ en/ev.php-URL ID=27234\&URL DO=DO TOPIC\&URL SECTION=201.html

United Nations (UN). (1992a). Rio Declaration on environment and development. UN publications. Retrieved March 28, 2009, from http://www.unep.org/ Documents.Multilingual/Default.asp?DocumentID=78\&ArticleID=1163

United Nations (UN). (1992b). Press Summary of Agenda 21 - Final Text. UN Conference on Environment and Development, Rio de Janeiro, Brazil, 3-14.

\section{Correspondence:}

Lolita Jonāne, doctoral student, Faculty of Natural Sciences and Mathematics, Daugavpils University, Parades 1, Daugavpils, LV-5400, Latvia.Email: lolitaj@inbox.lv

Received 30 January, 2009; revised version received 2 April, 2009 